ISSN: $2386-9658$

\title{
Unas palabras sobre Actores vestidos de calle
}

\author{
LUISA CASTRO \\ dirbur@cervantes.es \\ Directora del Instituto Cervantes de Burdeos
}

\section{EL ORDEN}

Los poemas que componen este libro estaban en origen ordenados de otra manera. Hay un orden natural en él, que yo alteré en los últimos días antes de entregarlo al editor, de modo que la composición final del libro no responde a la original. Mi empeño era encontrar su orden secreto, que yo intuía debajo del orden natural o cronológico. En el orden del libro hay, por tanto, un proceso de montaje, de post-producción, como si fuera una película. Hay también, en ese montaje posterior, un empeño de comprender las claves que rigen el libro.

Es evidente, como Nuria Rodríguez Lázaro advierte, que el resultado no ha eliminado el esencial caos, pero es un caos "consciente", es decir, un caos sometido a un orden. Contraviniendo así las leyes del caos, que se expande, yo intenté someterlo, y procedí con el nuevo orden a una contracción del sentido. Esa torsión, producto de la búsqueda de un orden imposible, opera sobre todo el libro, donde no hay una progresión sino que cada poema parece tener su propia energía, su genealogía, como si fueran estallidos simultáneos en un campo de batalla, como, me imagino, puede ser un ataque por sorpresa, como ese mismo ataque terrorista con el que arranca el libro: la explosión inesperada de una violencia múltiple a la que no podemos de ningún modo responder, porque sucede en varios lugares al mismo tiempo, nos asedia. No sabemos si el lugar en el que estamos va a estallar la bomba o si, por el contrario, su estallido nos espera allí donde pensábamos huir. Su esencia disruptiva, por inesperada, es lo que desordena las coordenadas espacio-temporales de nuestra existencia. Lo que nos paraliza. Lo que convierte un suceso en una imagen inolvidable. Me pregunto ahora, a la luz de la intervención de Nuria, si no será esa la esencia misma del mal, la imposibilidad de atribuirle un orden, una coherencia, de modo que aquellos a quienes va dirigido jamás puedan desentrañarlo y por tanto, jamás puedan dejar de pensar en él. Para un escritor no existe otra clase de peor pesadilla que la ausencia de orden, que es como decir la ausencia de razón. Las pasiones, tal y como nos han enseñado, no son lo esencialmente humano. Lo esencialmente humano es la razón, es decir, la necesidad del dolor moral ante la sinrazón, la violencia gratuita, o un orden intrínseco es aquello que organiza y 


\section{LUISA CASTRO}

estructura lo intencional del poema. El orden de la ironía, por ejemplo, manda sobre la tragedia, nos permite verla desde otro ángulo (véase Shakespeare, o más cerca de nosotros Symborska). Pero a lo que sucede en estos poemas no podemos enfrentarnos con el arma habitual de los poemas, el distanciamiento, porque los poemas están estallando ahí, y sólo cabe describirlos, como el soldado que ha asistido a un combate, y lo cuenta.

\section{EL TIEMPO}

\section{EL LUGAR}

